OOPEN ACCESS

International Journal of Advanced Economics

P-ISSN: 2707-2134, E-ISSN: 2707-2142

Volume 3, Issue 2, P.No. 10-25, June, 2021

DOI: 10.51594/ijae.v3i2.228

Fair East Publishers

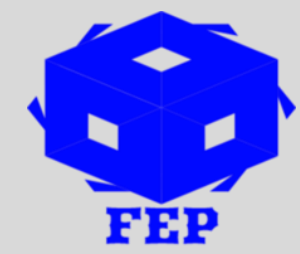

Journal Homepage: www.fepbl.com/index.php/ijae

\title{
EFFECTIVENESS OF AGRICULTURAL EXTENSION SERVICES TO MINIMIZE POST-HARVEST LOSSES OF HORTICULTURAL CROP PRODUCE WEST COAST REGION OF THE GAMBIA
}

\author{
Lamin K M Fatty ${ }^{1}$ 2, Prof. Idu Ogbe Ode ${ }^{2}, \&$ Bejamin Gowon Ahule ${ }^{2}$
}

${ }^{1}$ Benue State University, Centre for Food Technology and Research, Department of Sociology; Faculty of Social Sciences, Makurdi, Nigeria and University of The Gambia, School of Agriculture and Environmental Sciences, Brikama Campus, Banjul, The Gambia

${ }^{2}$ Benue State University, Centre for Food Technology and Research, Department of Sociology; Faculty of Social Sciences, Makurdi, Nigeria

*Corresponding Author: 1kmfatty@utg.edu.gm

Corresponding Author Email:

Article Received: 29-04-20

Accepted: 12-05-21

Published: 06-06-21

Licensing Details: The author retains the right to this article. The article is distributed under the terms of the Creative Commons Attribution-Non-Commercial, 4.0 License

(http://www.creativecommons.org/licences/by-nc/4.0/) which permits non-commercial use, reproduction, and distribution of the work without further permission provided the original work is attributed as specified on the Journal open access page.

\begin{abstract}
The study examines agricultural extension services and post-harvest technology of horticultural crop produce for smallholder farmers in West Coast Region of The Gambia. The objective of the study is to examine the effectiveness of agricultural extension services in minimizing postharvest losses of horticultural crop produce. The instruments designed to gather the primary data include; structured interview and focus group discussions (FGD) and key informant interview supported by secondary data using official documents. The sample population consisted of three hundred and ninety-eight (398) respondents using a minimum sample calculation of Taro Yamane in which ten extension officers (10) and two extension agent heads (2) as key informants for a period of three months from September to November 2017. This study employs cluster, purposive and simple random sampling procedures to draw its population. The data was quantitatively analyzed using SPSS to run percentages, frequency distribution tables, t-test, chi-squared correlation test and factorial analysis. Qualitative data from the in-depth interviews and FGDs were also analyzed and presented appropriately. The
\end{abstract}


findings of the study showed that extension services are not very much effective or proactive to post-harvest loss reduction in this region. The study recommends there is the need for continued research, development and investment programme in both extension and post-harvest technologies, effective and efficient communication to the farmers, special extension agents training on post-harvest practices among others.

Keywords: Agricultural Extension Services, Effectiveness, Post-Harvest Losses, Horticultural Crop Produce, Smallholder Farmer, The Gambia

\section{Background}

\section{INTRODUCTION AND LITERATURE REVIEW}

Smallholder vegetable farmers have been given little attention with regards to appropriate extension and research, and the situation is still similar today. Extension of inappropriate services often results in the lost chance of essential capacity building opportunities. Research therefore, emphasises the important role of capacity building where farmers are taught good farming and handling practices (Martins, Hogg, \& Otero, 2012).

The Gambia's agriculture faces numerous constraints that are mostly structural: difficulties in access to lands; under-utilized potential for land irrigation of 6\%; poor farming practices (inadequate improved seeds and fertilizers); large post-harvest losses (up to $40 \%$ ) due to insufficient and inefficient storage capacities; limited processing capacities and lack of access to markets and financial capital (GNAIP, 2011). According to FAOSTAT (2011), rice (which is the main staple food) and maize yields in The Gambia are low and lagging behind West Africa's average performance. Therefore, the national cereal production covers only $60 \%$ of the demand. In addition, limited public expenditures allocated to the agriculture sector $4.5 \%$ in 2010 according to the Gambia National Agricultural Investment Programme (GNAIP, 2011), and effects of the global financial crisis further constrains the implementation of agriculture and food security programmes. Access to food is undermined by low purchasing power, volatile food prices, and the depreciation of the national currency vis à vis the United State dollar significantly affecting Gambians who rely heavily on rice imports (up to 40\%). In 2011, prices of coarse grains were on average $40 \%$ higher than those of 2008 during the food crisis.

According to Department of Agriculture (DOA, 2013), the Ministry of Agriculture (MOA) in The Gambia is tasked with the responsibility of policy formulation and administration of all agricultural programmes projects and policies including the extension sector. Under it there are four sub-departments, each with distinct roles in the agricultural policy, programme and project implementation process. The four major sub-departments are: Department of Agriculture (DOA), Department of livestock Services (DLS), National Agricultural Research Institute (NARI) and Central Project Coordination Unit (CPCU). The Extension service is an agent of the Government currently monovalent, and has been undergoing restructuring for the past few years, aimed at ensuring effective and efficient service delivery. According to Agriculture and Natural Resource Programme (ANRP, 2009), the service is currently relying mainly on agricultural projects for capacity building as well as support to farmer training. The service is presently understaffed at field level with an Extension Worker/farmer ratio of over 1: 2000. Nearly $70 \%$ of the highly professional qualified personnel will reach retirement within the next five years, raising the need for an urgent up scaling of the sub-sector's human capacity in order to meet emerging challenges. The sector's objectives are focused on development of the small producers for productivity and competitiveness. The extension service will be central to get the necessary messages across to the small holders who may not have had the opportunity to see, 
let alone adopt new technologies especially in post-harvest losses. Thus, the benefit of postharvest technology of horticultural farmers will improve their income, surplus to the market for to sale and consume available food to the community which will results to poverty reduction. A good agricultural extension services establishment at post-harvest technology can contribute a lot to the food loss reduction, improve farmers' income status, standard of living, increase income and poverty reduction.

\section{Problem Statement}

There is no or little research shown on the effectiveness and efficiency of agricultural extension service on post-harvest losses of horticultural crop produce among smallholder farmers in Kombo Central and North of West Coast Region, The Gambia. This is supported by (GOTG, 2008, report and GOTG, 2010) that there is limited post-harvest/ processing/transformation and weak storage facilities; and access to consistent, appropriate technical field delivery services. This is a gap the research seeks to fill to examine the efficiency of agricultural extension services among the smallholder farmers, as well as investigate means to facilitate available storage and processing industries on reducing post-harvest loss of horticultural crop produce among smallholder farmers in West Coast Region, The Gambia.

\section{Objective of the Study}

The objective of the study is to determine the effectiveness of agricultural extension services in minimising post-harvest losses in West Coast Region of The Gambia. The study answered how effective will be agricultural extension service in minimizing post-harvest technology in Kombo Central and North District of West Coast Region of The Gambia?

\section{Effectiveness of and Extension Services and Post-Harvest Technology}

The primary goals of research on post-harvest technology of fresh produce are to reduce losses in quantity and quality and to maintain safety between harvest and consumption sites. The strategies for attaining these goals include: growing cultivars that have good flavour and nutritional quality plus long postharvest-life potential when harvested at optimum maturity; using an integrated crop management system that maximizes yield without sacrificing quality; and using optimal post-harvest handling practices to maintain quality and safety of the food products. Recent studies and literature reviews confirm that post-harvest losses are still high at the farm, wholesale and retail levels, and that not much improvement in the overall percentage of losses can be documented from the 1970s to the present, despite active horticultural education and research programs in many countries.

According to many studies, farmers have been losing between $30 \%$ and $40 \%$ of the value of their fruits and vegetables before they reach the final consumer, (Kumar, 2006, Korsten, 2006, Weinberger, Genova II, and Acedo, 2008, Coulomb, 2008, and Nunes, 2009). These losses are observed at harvesting, during packing, transportation, in wholesale and retail markets, and during delays at different stages of handling.

Extension efforts and training needs differ by target group, and there are often difficulties in reaching smallholder farmers, women, youth, middlemen/traders and processors. Traders and middlemen have been generally ignored although they have a large impact on the final quality of fresh produce and its potential market value. While researchers have identified many potentially useful post-harvest technologies for use in developing countries, there is a lack of information regarding the costs and financial benefits of these post-harvest technologies, since costs are rarely documented during research studies. Technically useful practices therefore tend to be disregarded since there is no information on costs or their potential financial returns in different developing regions. Although extension services in developing countries are 
increasingly involved in providing educational programs and training activities on post-harvest topics, often there is a lack of follow-through and support after the training. Those participating in postharvest training may be convinced and willing to implement improved practices, but cannot do so when needed supplies, tools or equipment are not locally available. Even when users are initially provided with these tools and supplies as part of a training program or development project, there tends to be a lack of local support and services once the programs end.

According to Kitinoja et al., (2011), establishing a Post-Harvest Working Group in each country can be very useful in providing a forum for communications among all those concerned with postharvest biology and technology research and extension. Capacity building in post-harvest research is an obvious need in many developing countries and can be achieved via internships, faculty exchanges, human resource development for staff in university laboratories and research centres, laboratory upgrades, improved access to web-based information, and mentoring. Leadership training is an important component in capacity building and, while it has been well characterized, is often neglected (Zamani and Karami, 2006).

\section{Effects of Post-harvest losses of Horticultural Crop Produce}

A vegetable-rich diet is highly recommended for weight management as it is low in calories. The wide variations in vegetable colour, fragrance, taste and texture add interest and appeal to meals (AVDRC, 2010; Keatinge, Yang, Hughes, Easown, \& Holmer, 2011). In the least developing countries, the consumption of vegetables is declining (Rosen \& Shapouri, 2008). Access to vegetable rich diets is unaffordable for many of most poor households. A vicious cycle of poverty and malnutrition is prevalent in many African households, especially those in the rural areas whose incomes fall well below the poverty line (Vorster, 2010). As a result, micronutrient deficiencies are among the major concerns contributing to child mortality, impaired scholastic ability and low productivity in adults (Vorster, 2010). This is particularly sad because vegetables are one of the most readily available sources of many important nutrients.

Growing fruits and vegetables helps sustain livelihoods through employment creation thus reducing poverty (AVDRC, 2010). Compared to cereal production, horticultural production is regarded as a high value business because it generates higher profits and provides twice the amount of employment opportunities per hectare production (Minot \& Ngigi, 2004; Cock \& Voss, 2004). This sector also boosts foreign reserves by creating exports and also generates offfarm employment through value addition activities, such as the canning and packing industries (Weinberger et al., 2005). However, Parallel to this increase in production there is increase in postharvest losses. This situation can be improved by conserving as much produce as possible through the reduction of postharvest losses and waste (Gustavsson, Celderberg, Sonesson, van Otterdijk, \& Meybeck, 2011).

\section{The Horticulture Sector in The Gambia}

It is rapidly emerging as one of the key growth areas of The Gambian economy. The sector currently contributes about $4 \%$ to GDP on average, and over $65 \%$ of the agricultural labour force is involved in the sector. Horticultural production is presently an established key source of rural income, employment and food, making significant contribution to food security and poverty alleviation. Horticultural crops include tomatoes, onions, cabbage, eggplant, okra, peppers, lettuce, cucurbits, carrots, beans, citrus fruits, mangoes, cashew, papaya, banana, cucumber. These crops especially vegetables are grown in small plots by smallholder farmers on an individual basis and through communal gardens mainly managed by women (ANR, 2009) 
Smallholder plots are found in gardens where the major source of water for irrigation is groundwater through shallow hand dug or concrete lined wells. There are a few commercial horticultural enterprises such as Radville Farms and Gambia Horticultural Enterprise (GHE) as well as "Gambia is Good" - a non-profit horticulture marketing company and unique social business enterprise that links local farmers with the tourism market, managed by Concern Universal, and other NGOs. Nearly 88 percent of all women farmers in The Gambia are estimated to be engaged in individual or communal horticultural activities, which include the growing of perennial crops. Most of the vegetables are grown in the dry season (November to June) with limited yields and regard for quality. However, the gradual introduction of pest/disease and heat tolerant hybrid varieties is contributing to developing year-round production (ANR, 2009).

Over the last few years, there has been tremendous improvement in horticultural production in the country. A wide variety of high value tropical and off-season fresh fruits and vegetables are now grown in the Gambia primarily for exports and also for the domestic/tourist market. However, fruits and vegetable exports are less developed and mainly practised by commercial farms. Significant hectares are steadily being brought under horticultural production by both commercial farms and smallholder farmers. The demand for seedlings of high value horticultural crops (particularly fruits) has increased over the years and Government, NGOs and individuals are providing support to meet the demand. Women are predominant in horticultural activities especially the management of small gardens of vegetables and marketing the commodities. Government and International NGOs in collaboration with their local partners are involved in capacity building activities, including those of extension workers and farmers. The actions have significantly contributed to boosting local production over the last five years. The sub sector has enormous prospects for investment, exports, import substitution for the local tourism and entertainment industry. The local market for horticultural produce is underexploited, and there is increasing demand for tropical and off-season fresh fruits and vegetables in the lucrative European Markets. The sub sector however faces two major challenges; the first -a sustainable production of competitive products for high value external markets in Europe, the growing sub regional markets and its own local Tourist and entertainment markets; the second of ensuring a dynamic locally managed agribusiness in the sub sector to meet demand and supply requirements.

\section{The Constraints of Horticultural Sector}

High supplies of horticultural produce are realized mainly in the dry season due to scarcity of suitable rainy season cultivars, harsh weather, pest's problems and greater engagement of women in food production activities during the rainy season and costs of water for irrigation are high and threaten to reduce margins and create disincentives to investment. These are constraints that affect management of the fruits and vegetables that also results to food insecurity. The level of research support to the industry is low and may expose the industry to low competitive products and of course make it unattractive for further investment thus smallholder farmers food insecurity in the country. Inadequate local markets/market space in most of the areas, glut in markets, inadequate market outlets, particularly export markets, and lack of proper market information and promotion, which small holders or producer organisations could benefit from, and as such they could not participate well in the industry. The infrastructure to support higher returns to producers and marketers is low to discouraging with the farm to market roads very poor, (impassable during and after heavy rains); storage facilities to handle perishable commodities are mostly ground floor spaces in verandas of 
houses, rickety baskets or damaged wooden or plastic boxes; air cargo space during peak horticultural season are inadequate and air freight costs are high; processing and preservation technologies are low output, with far less quality products; all leading to loss of food in the future. There is very little institutional support for horticultural exporters. Export promotion which should be handled by Government Institutions and private and civil society organisations are at best an expressed intention; and Packaging materials are imported and costly, and land Tenure System not Amenable to Conservation Investment discouraging further innovation (ANR, 2009).

\section{METHODOLOGY}

Using a sample of 398 horticultural smallholder farmers who were clustered, purposive and randomly selected for this study, horticultural farmers data was gathered on socioeconomic characteristics, demography, agronomic practices, knowledge indicators, training and postharvest handling practices. The study used survey research design adopting the cross-sectional types and the subjects studied individuals in a particular group, organization or community, and for this case the subject of study is the horticultural farmers and agricultural extension services in WCR including some key informants for qualitative data. The target population in the study comprise of all the sampled horticultural farmers involved in fruits and vegetable farming in Kombo Central and North, Agriculture Extension Agents and heads of district agricultural officers in the study area. The study use cluster, purposive and random sampling method in order to reach to a conclusion and the data for this study was elicited from both primary and secondary sources and the basic instruments designed to gather the primary data include were the structured interview (SI) and focus group discussions (FGD) while secondary data however was collected using official documentation and expert interview for verification. The basic method that guided the use of the existing data includes: good knowledge of the data source and the ability to extract the relevant information from the data, flexibility to ensure that the research problems can be answered with the help of such existing data, and the need to cross-check the validity and reliability with the information obtained .The study used multiple sources of information, both primary and secondary (referred as triangulation) to ensure construct validity and reliability of the data collected and the interview schedule was divided into 4 sections A, B, C, and D. Section A seeks and collects demographic data of the respondents. Key informant interviews with agricultural extension agents and head officers were conducted to obtain information on horticultural crop produces in order to verify and validate the accuracy of some of the information supplied by respondents' farmers; as well as agricultural extension agents' approaches, constraints, visits, monitoring systems in guiding the farmers on post-harvest handling techniques. Six focus group discussions sessions were organised comprising of 6-10 discussants per each session in each horticultural scheme. The data generated in this study were analysed both qualitatively and quantitatively in nature such as percentages, frequency distribution tables, t-test, chi-squared correlation test and furthermore analysed on qualitative means.

\section{RESULTS AND DISCUSSION}

This chapter concerns itself with the presentation and analysis of the data gathered. The analyses address the key questions of the study and highlight the social changes and adoptions of horticultural farmers in pursuance towards post-harvest practices in West Coast Region. In order to ascertain the overall significance of each variable on the influential factors correlation was used. 


\section{Socio-Demographic Data of the Respondents}

In the course of this study, certain characteristics were identified as representative of the sampled demographic variables for the horticultural farms in the area. These characteristics include gender, age, marital status, educational attainment, occupation, and income as presented in Table 2 below. Information on Table 1 below indicated that in terms of gender composition, $34(9 \%)$ respondents were males while $364(91 \%)$ were female. Data on age also indicated that $61(15.2 \%)$ of respondents were young people with an age category of $14-25$ years, 107 (26.7\%) respondents were of youth category with age bracket of 26-37 years, 110(27.4\%) respondents were another youthful age of active workforce with age range of 38- 49 years, 92 (22.9\%) respondents were adults of $50-61$ years and $32(8 \%)$ respondents aged from 62 years and above. With regards to marital status, $351(88 \%)$ respondents were married, whereas $47(12 \%)$ respondents were of the single category.

Furthermore, the study also found out that 333 (57.96\%) respondents did not have any formal education for both male and females, $42(10.45 \%)$ respondents had attended and/or completed primary level of education, $85(25.36 \%)$ respondents had attained secondary school level, 6 $(1.5 \%)$ respondents had attended tertiary (certificate/diploma level, $3(0.75 \%)$ respondents had attended university level and while $33(8.21 \%)$ respondents attained Arabic education. Also, with regards to occupation, $374(93 \%)$ respondents had farming as their dominant occupation, $10(2.5 \%)$ respondents had regular salary job, $1(0.2 \%)$ respondents were temporary job, 1 $(0.2 \%)$ respondents were unemployed, $8(2 \%)$ respondents were self-employed (petty trade or small business) while $8(2 \%)$ respondents were retired civil servants.

Finally, the statistics on respondents' current income status as shown on the table depicts that $353(89 \%)$ respondents were living on income less than Gambian Dalasi (GMD) D5,000.00 per annum (equivalent of USD 106.38 per annum), 20 (5\%) respondents were on annual income of GMD5, 000 - 10, 000 (equivalent of USD 106.38 - USD212.77 per annum), 10 (3\%) respondents were on annual income of GMD10,0001 - 15, 000 (equivalent of USD212.79 USD319.15 per annum) whereas, 5 (1\%) respondents were earning an annual income of Above GMD15, 001 (equivalent of USD 319.17 per annum). All these variables had in one way or the other influenced the acceptance or the adoption of new innovation of post-harvest loss reduction as can be seen in further discussions.

From the findings, more than two-third (364 (91\%) of the respondents were female farmers meaning males' involvement in horticultural production is very low (34 (9\%) thus less support for females. It was apparent that horticultural production has being going for years, $25-61$ years of respondents' farmers engaged in horticultural production showing a positive response to the involvement in the youth sector as they are the most energetic and productive population. However, only a frequency of $32(8 \%)$ of the farmers are engaged in horticultural production meaning not a good number has experience in the sector with only a few young people engagements in the sector. This implies that in the area, majority of younger people just form the seasonal labour supply but less experience in horticultural production.

With 351 (88\%) number of marriage respondents of the farmer, there is likelihood of high responsibility among the farmers which in some way could affect their involvement in the production and post-harvest loss reduction implying that there will be less serious attention to introduction of new innovations. 
Table 1

Socio-Demographic Characteristics of Respondents

\begin{tabular}{|c|c|c|}
\hline Variables & Frequency & Percentage \\
\hline A. Gender Distribution of Respondents & $(\mathrm{N}=398)$ & $(\%=100)$ \\
\hline Male & 34 & 9 \\
\hline \multirow[t]{2}{*}{ Female } & 364 & 91 \\
\hline & 398 & 100.0 \\
\hline \multicolumn{3}{|c|}{ B. Age Distribution of Respondents in Years } \\
\hline $14-25$ yrs. & 61 & 15.2 \\
\hline $26-37$ yrs. & 107 & 26.6 \\
\hline $38-49$ yrs. & 110 & 27.4 \\
\hline 50-61 yrs. & 92 & 22.9 \\
\hline 62 yrs. and above & 32 & 8.0 \\
\hline Total & 398 & 100.0 \\
\hline \multicolumn{3}{|l|}{ C. Respondents' Marital Status } \\
\hline Married & 351 & 88 \\
\hline Single & 47 & 12 \\
\hline Total & 398 & 100.0 \\
\hline \multicolumn{3}{|l|}{ D. Respondents Educational Attainment } \\
\hline \multicolumn{3}{|l|}{ Male } \\
\hline None & 7 & 1.74 \\
\hline Primary & 1 & 0.25 \\
\hline Secondary & 18 & 4.48 \\
\hline Tertiary & 3 & 0.75 \\
\hline University & 1 & 0.25 \\
\hline Arabic & 4 & 1.00 \\
\hline Total & 398 & 100.0 \\
\hline \multicolumn{3}{|l|}{ Female } \\
\hline None & 226 & 56.22 \\
\hline Primary & 41 & 10.20 \\
\hline Secondary & 67 & 16.67 \\
\hline Tertiary & 3 & 0.75 \\
\hline University & 2 & .50 \\
\hline Arabic & 29 & 7.21 \\
\hline Total & 398 & 100.0 \\
\hline \multicolumn{3}{|l|}{ E. Respondents' Occupation } \\
\hline Farming & 374 & 93.0 \\
\hline Regular Salary Job & 10 & 2.5 \\
\hline Temporary & 1 & .2 \\
\hline Unemployed & 1 & .2 \\
\hline Self-Employed & 8 & 2.0 \\
\hline Retired & 8 & 2.0 \\
\hline Total & 398 & 100.0 \\
\hline \multicolumn{3}{|c|}{ G. Income Distribution of Respondents Per Annum (D) } \\
\hline Below 5,000 & 353 & 89 \\
\hline $5,001-10,000$ & 20 & 5 \\
\hline $10,001-15,000$ & 10 & 3 \\
\hline Above 15,001 & 5 & 1 \\
\hline Total & 398 & 100.0 \\
\hline
\end{tabular}

(Source: Field survey, 2017)

One hundred and twenty-seven or (31.6\%) of male and female horticultural farmers in the study area had acquired formal education at primary to junior secondary level and at above primary level only 4 (1\%) male respondents' formal education, while $233(57.96 \%)$ of both male and female respondents had acquired no education at any level of education. The most educated horticultural farmers that had completed university education were only $0.75 \%$ ( 1 male and 2 female). Thus, high literacy level would imply that horticultural farmers are likely to synthesize information and appreciate the new technology and involve in post-harvest technology which lacked in the region. A similar study assesses knowledge of food hygiene of professional food 
handlers from an institutional catering company which manufactures and distributes meals to the canteens of schools, kindergartens and nursing homes by Martins et al. (2012) revealed that the level of knowledge among handlers was influenced by their level of formal education.

Ninety-three percent of the horticultural farmers comes from farming activities. Other off-farm employment activities are regular salary job, temporary, unemployed, self-employed and retired just few percent. This shows that in both districts the percentage of horticultural farmers depend on farming where the income obtain does not suffice the survival of the family.

\section{Effectiveness of Extension Services to Horticultural farms/Farmers}

The data as presented in Table 2 show the frequency and percentage achievement of horticultural farmers in the following variables: income earned, quantity of loss, training type conducted, post-harvest practices and number of training with respect to effectiveness indicators.

The result shows that there exists a high level of awareness among farmers about the existence of extension agents. The level of availability or awareness was found to be $276(69.3 \%)$ while few $122(30.7 \%)$ indicated they were not available to them. This is where extension effectiveness is higher too.

The result shows that in term of income earned per year 358 (89.9\%) were above D5, 000 (US\$105.26), 20 (5\%) were D5001 - 10,000 (US\$ 105.28 - 210.53), 10 (2.5\%) were D11,001 - 15,000 (US\$231.60 - 315.79) and 10 (2.5\%) were above D15,000 (US\$315.79). In term of quantity loss, the results revealed that $141(35.4 \%)$ lost $10 \mathrm{~kg}$ of the produce after harvesting, 78 $(19.6 \%)$ lost $11-20 \mathrm{~kg}, 48(12.1 \%)$ loss of $21-30 \mathrm{~kg}, 30(7.5 \%)$ loss of $31-40 \mathrm{~kg}, 40(10.1 \%)$ loss of $41-50 \mathrm{~kg}, 20(5 \%)$ loss of $51-60 \mathrm{~kg}$ and $41(10.3 \%)$ loss of above $61 \mathrm{~kg}$.

Table 2

Effectiveness of Agricultural extension services by Horticultural Farms/Farmers

\begin{tabular}{|c|c|c|c|}
\hline \multirow{2}{*}{$\begin{array}{l}\text { Variables } \\
\text { Income Per Year }\end{array}$} & \multirow{2}{*}{ Below 5,000 } & \multicolumn{2}{|c|}{ Frequency $(\mathrm{N}=398)$ Percent $(\%=100)$} \\
\hline & & 358 & 89.9 \\
\hline & $5,001-10,000$ & 20 & 5.0 \\
\hline & $11,001-15,000$ & 10 & 2.5 \\
\hline & Above 15,000 & 10 & 2.5 \\
\hline & Total & 398 & 100.0 \\
\hline \multirow[t]{8}{*}{ Quantity Loss } & $0-10 \mathrm{~kg}$ & 141 & 35.4 \\
\hline & $11-20 \mathrm{~kg}$ & 78 & 19.6 \\
\hline & $21-30 \mathrm{~kg}$ & 48 & 12.1 \\
\hline & $31-40 \mathrm{~kg}$ & 30 & 7.5 \\
\hline & $41-50 \mathrm{~kg}$ & 40 & 10.1 \\
\hline & $51-60 \mathrm{~kg}$ & 20 & 5.0 \\
\hline & 61 Above & 41 & 10.3 \\
\hline & Total & 398 & 100.0 \\
\hline \multirow[t]{5}{*}{ Training Type } & Handling & 1 & 0.3 \\
\hline & Packaging & 1 & 0.3 \\
\hline & Others (Grading, Sorting) & 31 & 7.8 \\
\hline & No Training & 365 & 91.7 \\
\hline & Total & 398 & 100.0 \\
\hline \multirow[t]{3}{*}{ Post-Harvest Practices } & Yes & 37 & 9.3 \\
\hline & No & 361 & 90.7 \\
\hline & Total & 398 & 100.0 \\
\hline \multirow[t]{6}{*}{ Number of training Done } & Weekly & 4 & 1.0 \\
\hline & Monthly & 1 & 0.3 \\
\hline & Yearly & 4 & 1.0 \\
\hline & Others (During Taiwanese Time) & 21 & 5.3 \\
\hline & None & 368 & 92.5 \\
\hline & Total & 398 & 100.0 \\
\hline \multirow[t]{3}{*}{ Availability of AESs } & Yes & 276 & 69.3 \\
\hline & No & 122 & 30.7 \\
\hline & Total & 398 & 100.0 \\
\hline
\end{tabular}


In respect to post-harvest practices training conducted, only 37 (9.3) affirmed that they attended while $361(90.7 \%)$ never attended post-harvest practice training. The results on training type only $3(0.75 \%)$ said the training conducted was handling of produce, $3(0.75 \%)$ on packaging, $31(7.8 \%)$ on others which is identified as grading and sorting and $361(90.7 \%)$ on no training attended especially in relation to post-harvest practices. The results in the number of training done, only $4(1.0 \%)$ affirmed that they had weekly training, $8(2 \%)$ on monthly, $4(1 \%)$ on yearly, $21(5.3 \%)$ on others identified as during Taiwanese time, and $360(90.5 \%)$ had not any training.

\section{Agricultural Extension Effectiveness on Methods Applied to the Post harvest Loss}

The data as presented in Table 3 show the frequency and percentage achievement of horticultural farmers in the following variables on methods applied in training farmers: field meetings, regularity of visits, field days, demonstrations, supervision, research and farmer training.

The performance of the Kombo Central and North as shown in the table 3 below in effectiveness indicators were as follows: method of field meeting $223(56 \%)$ as not effective and $175(44 \%)$ a combination of effective and very effective, regularity of visits as $221(55.5 \%)$ as not effective and $177(44.4 \%)$ a combination of effective and very effective, field days 205 $(51.5 \%)$ as not effective and $193(48.5 \%)$ combination of effective and very effective, demonstrations conducted 219(55\%) not effective and $179(45 \%)$ effective and very effective combined, supervision as $222(55.8 \%)$ not effective and $176(44.3 \%)$ effective and very effective combined, research $216(54.3 \%)$ not effective and $182(45.8 \%)$ effective and very effective combined while the last method- farmer training as $204(51.3 \%)$ as not effective and 194 (48.7\%0 as effective and very effective.

The result shows that the high performance of extension effectiveness is on field meeting which is a fairer performance while the lowest performance in effectiveness is organisation of field days and farmer training programmes in horticultural farms. However, the average percentage achievement of $62.9 \%$ of set targets is considered good. But the poor effectiveness in Farm and farmer training and even other method is a matter for concern. The study found the average percentage level of effectiveness of extension activities to be $62.9 \%$. The findings of the study that poor extension delivery service, especially with regard to farmer-training programmes and research-extension-farmer activities was largely responsible for poor adoption of recommendations is corroborated by the findings of Chinaka et al. (2005) and Agbarevo, (2013) who reported that effectiveness of extension delivery influences adoption by farmers, and that, poor extension delivery would lead to poor adoption. There is no effectiveness of Agricultural extension services on minimising post-harvest losses of horticultural crop produce

Table 3

Agricultural Extension Effectiveness on Method Applied to Post-Harvest Loss

\begin{tabular}{|c|c|c|c|}
\hline Variables & & Frequency $(\mathrm{N}=398)$ & Percent $(100 \%)$ \\
\hline \multirow[t]{4}{*}{ Field Meeting } & Not Effective & 223 & 56.0 \\
\hline & Effective & 48 & 12.1 \\
\hline & Very Effective & 127 & 31.9 \\
\hline & Total & 398 & 100.0 \\
\hline \multirow[t]{4}{*}{ Regularity } & Not Effective & 221 & 55.5 \\
\hline & Effective & 65 & 16.1 \\
\hline & Very Effective & 112 & 28.1 \\
\hline & Total & 398 & 100.0 \\
\hline \multirow[t]{2}{*}{ Field days } & Not Effective & 205 & 51.5 \\
\hline & Effective & 48 & 12.1 \\
\hline
\end{tabular}




\begin{tabular}{l|lrr}
\hline \multirow{5}{*}{ Demonstration } & Very Effective & 145 & 36.4 \\
& Total & $\mathbf{3 9 8}$ & $\mathbf{1 0 0 . 0}$ \\
& Not Effective & 219 & 55.0 \\
& Effective & 67 & 16.8 \\
Supervision & Very Effective & 112 & 28.1 \\
& Total & $\mathbf{3 9 8}$ & $\mathbf{1 0 0 . 0}$ \\
& Not Effective & 222 & 55.8 \\
Research & Effective & 48 & 12.1 \\
& Very Effective & 128 & 32.2 \\
& Total & $\mathbf{3 9 8}$ & $\mathbf{1 0 0 . 0}$ \\
Farmer Training & 216 & 54.3 \\
& Not Effective & 62 & 15.6 \\
& Effective & 120 & 30.2 \\
& Very Effective & $\mathbf{3 9 8}$ & $\mathbf{1 0 0 . 0}$ \\
& Total & 204 & 51.3 \\
& Not Effective & 63 & 15.8 \\
& Effective & 131 & 32.9 \\
& Very Effective & $\mathbf{3 9 8}$ & $\mathbf{1 0 0 . 0}$ \\
\hline
\end{tabular}

(Source: Filed Survey, 2017)

Table 3 shows the Chi square relationship between extension services influence on post-harvest loss practices on loss of crop produce. A chi-square test was performed and a significance relationship was found between all the variables stated and the frequency of farmers perception of extension services on crop produce loss, $\mathrm{X}^{2}(\mathrm{~N}=398)=0.05, \mathrm{p}=0.000$. The result showed that there is significant relationship between extension services and post-harvest loss of crop produce of horticultural crops. This indicates that variables such as income per year, quantity loss, post-harvest practices, type of training, number/times of training conducted, availability of extension agents, and times of extension visits at $(\mathrm{r}=0.05, \mathrm{p}<0.000$, ) all does show a significant relation on post-harvest losses of crop produce to horticultural farmers.

The results of chi-square in table 4 below indicated that all these variables show a significant relation between horticultural farms and extension effectiveness in the methods applied at the farms. In each case p-value is less than the expected significant level of 0.05 , such as income per year $\left(X^{2}(15)=40.751^{a}, p<0.00\right)$, quantity loss $\left(X^{2}(30)=309.381^{a}, p<0.000\right)$, postharvest practices training $\left(X^{2}(5)=35.255^{\mathrm{a}}\right)$, type of training $\left(X^{2}(15)=52.322^{\mathrm{a}}, \mathrm{p}<0.000\right)$, number of training conducted $\left(\mathrm{X}^{2}(20)=70.225^{\mathrm{a}}, \mathrm{p}<0.000\right)$, availability of agricultural extension agents $\left(X^{2}(5)=114.233^{\mathrm{a}}, \mathrm{p}<0.000\right)$, times of agricultural extension visits $\left(X^{2}(20)=\right.$ $\left.370.128^{\mathrm{a},} \mathrm{p}<0.000\right)$ and effectiveness of agricultural extension services $\left(\mathrm{X}^{2}(10)=35.182\right.$, $\mathrm{p}<$ $0.000)$ were all significant on post-harvest practices at $\mathrm{p}<0.05$ level of significance. This implies that availability of extension agents to the horticultural farms are significant to have an impact on access the agricultural information. The availability of extension and the frequency with which they receive from the extension service was statistically high for majority of the members in the schemes. It means that there is significant relationship between extension awareness and post-harvest handling at $p<0.05$ level of significance. This has been reported during FGD with frequent visit and training on post-harvest practices, a lot of improvement can be done in reducing post-harvest losses. This was supported by Adijah, Kathuri, and Wesonga, (2013) that extension service should be facilitated to use group demonstrations and group meetings to pass innovations for effective implementation.

Therefore, based on the results obtained from the table below (4), It can be analysed that the $p$ values for all the variables were less than 0.05 , which shows that there is significant relationship with horticultural farms and extension effectiveness. This also conclude that the hypothesis is rejected. We then reject the null hypothesis, and conclude that there is an association or significance between horticultural farms and extension effectiveness agriculture and accept the 
alternative hypothesis that there is significance influence. It appears that with extension services delivery, access, and method at horticultural farms should be efficiently coordinated for nay successful accomplishment.

Similarly, the findings from the key informants are also in line with the above assessment;

"Despite the visits, training and monitoring provided to the some of the horticultural farms/farmers post-harvest practices were not effectively carried out due to limited/inadequate skills and knowledge from the extension agents. This is peculiar with the all the horticultural farms (in-depth interview/Banjuluding Station, 2017).

Table 4

Effectiveness of Agricultural Extension Services at Horticultural Farms

\section{Chi-Square Tests}

Horticultural Farms

\begin{tabular}{|c|c|c|c|}
\hline $\begin{array}{l}\text { Effectiveness of Agricultural Extension } \\
\text { Services }\end{array}$ & $\begin{array}{r}\text { Person Chi- } \\
\text { Square }\end{array}$ & df & $\begin{array}{r}\text { Asymptotic Significance (2- } \\
\text { sided) }\end{array}$ \\
\hline Income Per Year & $0.000 \quad 40.751^{\mathrm{a}}$ & 15 & 0.05 \\
\hline Quantity Loss & $0.000309 .381^{\mathrm{a}}$ & 30 & 0.05 \\
\hline Post-Harvest Practices Training & $0.000 \quad 35.255^{\mathrm{a}}$ & 5 & 0.05 \\
\hline Type of training Conducted & $0.000 \quad 52.322^{\mathrm{a}}$ & 15 & 0.05 \\
\hline Number/ Times of Training Done & $70.225^{\mathrm{a}}$ & 20 & 0.05 \\
\hline $\begin{array}{l}\text { Availability of Agricultural Extension } \\
\text { Agents }\end{array}$ & $0.000114 .233^{\mathrm{a}}$ & 5 & 0.05 \\
\hline Times of Agricultural extension Visits & $0.000370 .128^{\mathrm{a}}$ & 20 & 0.05 \\
\hline Effectiveness of Agricultural Extension Ser. & 35.182 & 10 & 0.05 \\
\hline
\end{tabular}

\section{Horticultural Farm s/Farmers Perception of Agricultural Extension Effectiveness}

Table 5 presents further hypothesis of the chi-square test between agricultural extension services and horticultural farms on other methods of delivery, access, and availability of the respondents. The results reveal that the tabulated $\mathrm{X}^{2}$ value at $0.05 \%$ level of significance were as follows: field meeting, regularity, filed days, demonstration, supervision, research and farmer training. On field meetings produced $\left(X^{2}(10)=39.853^{\mathrm{a}}, \mathrm{p}<0.000\right)$, regularity $\left(\mathrm{X}^{2}(10)=52.53^{\mathrm{a}}\right.$ $, \mathrm{p}<0.000)$, field days $\left(\mathrm{X}^{2}(10)=59.037^{\mathrm{a}}, \mathrm{p}<0.000\right)$, demonstration $\left(\mathrm{X}^{2}(10)=55.585^{\mathrm{a}}, \mathrm{p}<\right.$ $0.000)$, supervision $\left(X^{2}(10)=40.544^{\mathrm{a}}, \mathrm{p}<0.000\right)$, research $\left(\mathrm{X}^{2}(10)=51.603^{\mathrm{a}}, \mathrm{p}<0.000\right)$ and farmer training $\left(X^{2}(10)=63.364^{\mathrm{a}}\right.$, Since the computed $\mathrm{X} 2$ value is less than the tabulated 0.05 value, then we reject the null hypothesis and hence, conclude that there is significant relationship between horticultural farms and agricultural extension services effectiveness of the respondents in delivery, access and method of applying services in the study area. Similar studies were conducted by (Gwary et al; 2013). This implies that if extension services are efficiently and effectively applied to the farms, this will help minimise post-harvest loss of horticultural crop produce.

Pearson chi-square values shown in table 5 below are used to show whether there is some association on the selected variables with the extension services and post-harvest loss of horticultural crop produces. Results in table 5 above show that the variables availability of AES, extension visit, farm size, age, household size, marital status, experience in farming, education, farm group, transportation type, post-harvest technology training and distance to market are significantly associated with the horticultural smallholder farmers post-harvest losses. The 
variables age, is significant at $90 \%$ significance level; farm size, marital status, experience in farming and education are significant at $95 \%$ significance level; and availability of AES, extension visit, farm group, transportation, post-harvest technology training and distance to markets are significant at $99 \%$ significance level. These results show that institutional factors top the list of variables that are closely associated with post-harvest losses of horticultural crop losses. Since the results obtained from the analysis indicated that there is significant level from the variables on extension significance influence on post-harvests losses, we can accept that extension services have high significance to help improve post-harvest losses of horticultural crop produce if actually there is effective and efficient operation at the horticultural farms, there would be less post-harvest losses.

Table 5

Horticultural Farmers Perception of Extension services Effectiveness on Method Applied Chi-Square Tests

\begin{tabular}{l|rrrrr}
\hline & \multicolumn{5}{|c}{ Horticultural Farmers } \\
Variables & $\begin{array}{r}\text { No. of valid } \\
\text { Cases }\end{array}$ & $\begin{array}{r}\text { Pearson Chi- } \\
\text { Square }\end{array}$ & Value & Df & $\begin{array}{r}\text { Asymptotic Significance (2- } \\
\text { sided) }\end{array}$ \\
\hline Field Meeting & 398 & 0.000 & $39.853^{\mathrm{a}}$ & 10 & 0.05 \\
Regularity & 398 & 0.000 & $52.535^{\mathrm{a}}$ & 10 & 0.05 \\
Field days & 398 & 0.000 & $59.037^{\mathrm{a}}$ & 10 & 0.05 \\
Demonstration & 398 & 0.000 & $55.585^{\mathrm{a}}$ & 10 & 0.05 \\
Supervision & 398 & 0.000 & $40.544^{\mathrm{a}}$ & 10 & 0.05 \\
Research & 398 & 0.000 & $51.603^{\mathrm{a}}$ & 10 & 0.05 \\
Farmer & 398 & 0.000 & $63.364^{\mathrm{a}}$ & 10 & 0.05 \\
Training & & & & & \\
\hline
\end{tabular}

$\mathrm{n}=398$; Correlation is significant at the 0.01 level (2-tailed); correlation is significant at the 0.05 level (2-tailed).

(Source: Field Survey, 2017)

Similarly, the findings from the FGD and key informants are also in line with the above assessment;

"Despite the training provided to the Water User Associations in targeted rice perimeters by the SWMU coupled with sensitization conducted by DCD, the key irrigation infrastructures are rarely maintenance. This is peculiar with the main, secondary and tertiary canals. Tall grasses are found in most of the canals that were de-silted thus rendering water management systems difficult resulting low production and productivity". (in-depth interview/Banjul, 2018).

In conclusion to these hypotheses that: there is no effectiveness of Agricultural extension services and reduction in post-harvest losses of horticultural crop produce is accepted. This has been proved in the two analysis that shows the relationship of extension service with horticultural farms on the availability and effectiveness of the activities carried out to help improve post-harvest losses of horticultural crop produce. Similar results have been collaborated by the findings of Bindu, S. and Chigusiwa, L. (2013).

\section{CONCLUSION AND RECOMMENDATIONS}

This chapter presents the main conclusions of the study and based on the empirical results, the chapter also draws several policy recommendations towards agriculture extension services and post-harvest loss reduction. In addition, the last section of this chapter presents the suggestions for areas of further exploration in the future. 


\section{Conclusions}

The following conclusions are drawn from this study: the current horticultural post-harvest loss management and access to relevant information from the stakeholders and the diverse financial status of farmers are not properly considered to curb access to extension services and postharvest practices, in the design, and implementation of a workable dissemination and promotion strategy for the proposed technology. The study concluded that on the demographic characteristics, most of the horticultural farmers are females at an average age of 48 years, and the maximum educational level at junior secondary school and majority have not had formal education. Majority of farmers used farming as their main source of income and further away a distance from the market is from the farm, all contribute to the higher post-harvest losses. The study also concluded that the bigger the farm size, the higher the losses, a finding supported by several studies revealed in previous sections. However, in this study many of the farmers had a small hectare of land. We can also conclude that there was less effective and efficient system of extension services operation at all the schemes in relation to post-harvest handling as revealed from the hypotheses tests. In addition, on the site of the extension, the extension was not adequately equipped with the resources in both material, financial, moral and knowledge and skills to support minimisation of post-harvest losses of horticultural crop produces.

\section{Recommendations}

The identified determinants of post-harvest losses in smallholder horticultural crop producers provide useful acumens/insights for policy makers, advisers, developers and sellers of postharvest practices. This information can yield extensive products in terms of the development of quality post-harvest management and education programs as well as the design of more effective government policies. Due to the variation in socioeconomic, demographic, knowledge, skills and risk aversion, new technologies and smallholder development programs need to be tailored to the requirements of a particular group of farmers if they are going to be effective. Programmes can only be tailor made if government and development agencies are knowledgeable of the production and post-harvest handling challenges faced by the farmers, hence the need for continued research and development. Thus, the following recommendations are made:

1. Continued investment in agricultural research aimed at generating new and improving old technologies that could shift the production and post-harvest handling frontiers and improve their effectiveness should maintain and further improve productivity as well as minimise post-harvest losses and access to markets.

2. Government and other players in the agricultural sector plan initiatives to educate both extension agents and smallholder farmers on the benefits of proper post-harvest handling practices as an effective means to curb/limit the negative effects of fresh produce post-harvest losses.

3. Ministry of Agriculture and her partner institutions should collaborate for special extension agents trained on post-harvest practices to be provided to farmers at all levels such as regional, district, ward and village as most of the extension agents have little skills and knowledge on this sector.

4. Appropriate training of extension officers to ensure that they are well equipped specially on specific extension on post-harvest technology which is vital in post-harvest handling practices and technologies.

5. Farmers should use appropriate post-harvest handling practices to preserve desirable fresh produce quality characteristics and overall post-harvest loss reduction. 
6. Government policy with regard to horticultural smallholder farmer support should focus on facilitating the farmers to access reliable water supply for production.

\section{Acknowledgements}

I acknowledge the support of my supervisors Professor Idu Ogbe Ode and Dr. Benjamin Ahule, my special thanks to the Department of Sociology and Postgraduate Program of Benue State University. I am grateful to the staff of Sociology, Centre for Food Technology and Research and their technical assistance in conducting my course works and also thanks Government of The Gambia through the Ministry of Higher Education Research Science and Technology. My special thanks go to African Economic Research Consortium (AERC) for inviting me a training workshop in Ethiopia and sponsoring part of my research activities.

\section{References}

Adijah, M. A. O., Kathuri, N. J., \& Wesonga, T. E. O. (2013). Effective extension methods for increased food production in Kakamega District. African Journal of Agriculture and Food Security, 1(2), 043-048, September, 2013. Available online at www.internationalscholarsjournals.org (C) International Scholars Journals

Agbarevo, M. N. B. (2013). Farmers' Perception of Effectiveness of Agricultural Extension Delivery in Cross-River State, Nigeria. IOSR Journal of Agriculture and Veterinary Science (IOSR-JAVS) e-ISSN: 2319-2380, p-ISSN: 2319-2372. Vol. (2) 6

ANR, (2009). Agriculture and Natural Resources (ANR) Policy (2009-2015): The Republic of The Gambia: http://qanet.gm/statehouse/agriculture/achievements.html

Asian Vegetable Research Development Centre (AVRDC), (The World Vegetable Centre) (2010). Prosperity for the poor and health for all: Strategic plan 2011-2025. AVRDC, Publication, 10, 738-41. Shanhua, Taiwan.

Bindu, S., \& Chigusiwa, L. (2013). Examining the Sources of Smallholder Horticultural Farmers Exclusion from Formal Urban Markets in Zimbabwe: The Case of Chihota Communal Areas. International Journal of Economic Research, 4(6), 1-12.

Chinaka et al. cited in Imoh, A.N. and Essien, M.U., (2005). Adoption of improved cassava varieties among small scale farmers in IkotEkpene Zone of Akwa Ibom State in Nigeria, in M.A. orheruata, S.O. Nwokoro, M.T. Ajayi, A.T. Adekunle and G.N. Asumugha (eds.), Agricultural Rebirth for Improved Production in Nigeria. Proceedings of the 30th Annual Conference of the Agricultural Society of Nigeria held at the University of Benin, BeninCity, Edo State, Nigeria, October 9-13, 2005, pp.8-10

Cock, J.H., \& Voss, J. (2004). A passion for fruits: development of high value horticultural crops in Latin America. Acta Horticulturae (ISHS), 6, 57-67.

Coulumb, D. (2008). Refrigeration and the cold chain serving the global food industry and creating a better future: Two key IIR challenges for improving health and environment. Trends in Food Science and Technology, 19,413-417

Department of Agriculture. (2013). The Agricultural and Natural Resource Policy, Republic of The Gambia

FAOSTAT. (2011). Improving food security through crop production intensification and school feeding program - The Gambia - MDG initiative CRIS No GM/FED/023-838

Gambia National Agricultural Investment Plan (GNAIP), (2011). Government of The Gambia, The Gambia. Available from http://www.gafspfund.org/gafsp/sites/gafspfund.org 
Government of The Gambia (GOTG), (2010). The Gambia Country Paper and Action Programme 2001--2010 Third United Nations Conference on The Least Developed Countries, Brussels, 14-20 May 2001, A/CONF.191/CP/35

Government of The Gambia Report (GOTG), (2008). Initiative on Soaring Food Prices (ISFP), republic of The Gambia; Final Report Situation Assessment and Country Action Plan.

Gustavsson, J., Celderberg, C., Sonesson, U., van Otterdijk, R., \& Meybeck, A. (2011). Global food losses and food waste: Extent, causes and prevention, Food and Agriculture Organisation of the United Nations, Rome.

Gwary, M. M., Donye, A. O., Wakawa, R. C., \& Shallangwa, M. D. (2013). Constraints to Extension Service Delivery in the Production, Processing and Marketing of Gum Arabic in Magumeri Local Government Area of Borno State, Nigeria; Agriculture and Biology Journal of North America. Doi:10.5251/abjna.2013.4.2.126.131

Keatinge, J.D., Yang, H., Hughes, R.Y., Easown, W.J., \& Holmer, R. (2011). The importance of vegetables in ensuring both food and nutritional security in attainment of the millennium development goals. Food Security, 3,491-506.

Kitinoja, L., Saran, S., Roy, S.K., Kader, A.A. (2011). Postharvest technology for developing countries: Challenges and opportunities in research, outreach and advocacy. Journal of Food Science and Agriculture, 4, 597-603

Korsten L, (2006). Advances in control of postharvest diseases in tropical fresh produce. International Journal of Postharvest Technology Innovation, 1, 48-61

Kumar, D.K., Basavaraja, H., \& Mashajanshetti, S.B. (2006). An economic analysis of postharvest losses in vegetables in Karnataka. Indian journal of Agricultural Economics, 61, 134-146.

Martins, R.B., Hogg, T., \& Otero, J.G. (2012). Food handlers' knowledge on food hygiene: The case of a catering company in Portugal. Food Control, 23, 184-190.

Minot, N., \& Ngigi, M. (2004). Building on successes in African agriculture: are Kenya's horticultural experts a replicable success story?" IFPRI Focus 12, Brief 7 (April). Washington D.C.: International Food Policy Research Institute.

Nunes, M.C.N. (2009). Colour atlas of postharvest quality fruits and vegetables. pp. 239-245. Blackwell Publishing.

Rosen, S., \& Shapouri, S. (2008). Obesity in the midst of unyielding food insecurity in developing countries. Economic Research Service/USDA. Amber Waves, 6, 10-17.

Vorster, H.H., (2010). The link between poverty and malnutrition: A South African perspective. Health SA Gesondheid, North America. Journal of Interdisciplinary Health Sciences, 15(1), 1-8.

Weinberger, K., Genova II, C., \& Acedo, A. (2008). Quantifying postharvest loss in vegetables along the supply chain in Vietnam, Cambodia and Laos. International Journal of Postharvest Technology and Innovation, 1, 288-297.

Weinberger, K., Margit, L., \& Thomas, A. (2005). Horticulture for Poverty Alleviation: The Unfunded Revolution. AVRDC Working Paper 15. Shanhua, Taiwan: AVRDC

Zamani, G.H., \& Karami, E. (2006). Rural leadership and Sustainable agriculture: Criteria for Recruiting Leaders, Journal of Food Agriculture and Environment, 4, 3-4, WFL Publishing Science and Technology 